\title{
Distinct Expression Profiles of p63 Variants during Urothelial Development and Bladder Cancer Progression
}

\author{
Orit Karni-Schmidt, ${ }^{*}$ Mireia Castillo-Martin, ${ }^{*}$ \\ Tian HuaiShen, ${ }^{*}$ Nataliya Gladoun, ${ }^{*}$ \\ Josep Domingo-Domenech, * \\ Marta Sanchez-Carbayo, ${ }^{\dagger}{\text { Yingchun } \mathrm{Li}^{,}}^{\ddagger}$ \\ Scott Lowe, ${ }^{\S}$ Carol Prives, ${ }^{\ddagger}$ \\ and Carlos Cordon-Cardo*ף\|
}

\begin{abstract}
From the Herbert Irving Comprehensive Cancer Center," and the Departments of Biological Sciences, ${ }^{\ddagger}$ Pathology and Cell Biology, ${ }^{\text {"T }}$ and Urology, Columbia University, New York, New York; the Tumor Markers Group, ${ }^{\dagger}$ Spanish National Cancer Center, Madrid, Spain; and the Cold Spring Harbor Laboratories, ${ }^{\S}$ Cold Spring Harbor, New York
\end{abstract}

The TP63 gene, a member of the TP53 tumor suppressor gene family, can be expressed as at least six isoforms due to alternative promoter use and alternative splicing. The lack of p63 isoform-specific antibodies has limited the analysis of the biological significance of p63. We report a novel set of well-defined antibodies to examine p63 isoforms in mouse and human urothelium during embryogenesis and tumor progression, respectively. We provide evidence that basal and intermediate urothelial cells express p63 isoforms, with the TAp63 variant the first to be detected during development, whereas umbrella cells are characterized by a p63-negative phenotype. Notably, we report that p63-null mice develop a bladder with an abnormal urothelium, constituted by a single layer of cells that express uroplakin II and low molecular weight cytokeratins, consistent with an umbrella cell phenotype. Finally, analysis of 202 human bladder carcinomas revealed a new categorization of invasive tumors into basal-like (positive for $\Delta \mathrm{Np} 63$ and high molecular weight cytokeratins and negative for low molecular weight cytokeratins) versus luminal-like (negative for $\Delta$ Np63 and high molecular weight cytokeratins and positive for low molecular weight cytokeratins) phenotypes, with $\Delta$ Np63 expression associated with an aggressive clinical course and poor prognosis. This study highlights the relevance of p63 isoforms in both urothelial development and bladder carcinoma progression, with $\Delta$ Np63 acting as an oncogene in certain invasive bladder tumors. (Am J Patbol 2011, 178:1350-1360; DOI: 10.1016/j.ajpath.2010.11.061)

The TP63 gene is a member of the TP53 gene family that also includes TP73, which encodes at least six isoform proteins due to alternative promoter use and alternative splicing. ${ }^{1-4}$ The revelation of an internal promoter within this family was first attributed to TP63. ${ }^{4}$ TP63 has a domain topology similar to TP53, with an N-terminal transactivation domain, a central sequence-specific DNA-binding domain, and a C-terminal oligomerization domain. The two main groups of p63 isoforms generated by alternative promoter use include the TA isoforms, in which the $\mathrm{N}$-terminal transactivation domain is retained, and the $\Delta \mathrm{N}$ isoforms, which lack the TA domain. ${ }^{4}$ Although TAp63 has been shown to transactivate $p 53$ target genes, $\Delta N p 63$ can act both as dominant negative factor toward TAp63, p73, and p53, 5,6 and also possess transactivation activity. 7,8

In contrast to TP53, which plays critical roles in regulating multiple cellular pathways and is mutated in many human cancers (reviewed in references 9-11), TP63 is rarely mutated, ${ }^{12,13}$ and its role in cancer is not yet clarified. Data from mouse models are also inconclusive: although some studies show that $\mathrm{p} 63^{+/-}$mice are not tumor prone, ${ }^{14}$ other groups reported that $\mathrm{p} 63^{+/-}$mice developed spontaneous tumors, including squamous cell carcinoma and sarcomas. ${ }^{15}$

Despite the structural and partly functional identity among the TP53 family members, studies in knockout mice demonstrate significant functional differences among them. For example, studies in mice suggest a unique role for p63 in development, including its role in epidermis formation, ${ }^{5,6,13}$ maintenance of the proliferative potential of basal regenerative cells in stratified epi-

Supported by grants CA87497, CA47179, and CA13106 from the National Institutes of Health.

O.K.-S. and M.C-.M. made equal contributions to this study.

Accepted for publication November 9, 2010.

Address reprint requests to Carlos Cordon-Cardo, M.D., Ph.D., Department of Pathology, Herbert Irving Comprehensive Cancer Center, Columbia University, 1130 St. Nicholas Ave., Room 309, New York, NY 10032. E-mail: cc2791@columbia.edu. 
thelium, ${ }^{16,17}$ and serving as a molecular switch for initiation of an epithelial stratification program. ${ }^{18}$

Normal bladder is coated by a mucosa termed urothelium, a pseudo-stratified epithelium composed of basal, intermediate, and superficial umbrella cells. There are up to seven layers in human bladder urothelium and only up to three layers in the mouse bladder urothelium. ${ }^{19}$ It is well documented that the basal and intermediate cell layers are characterized by a nuclear p63-positive phenotype, along with the expression of high molecular weight cytokeratins (CKs), such as CK5 and CK14. In contrast, umbrella cells of the superficial layer display a distinct phenotype characterized by lack of p63 expression and presence of certain low molecular weight CKs, such as CK20 and CK18, as well as uroplakins [eg, uroplakin II (UPII) ${ }^{19,20}$ ]. Our group and others previously found that p63 is essential for urothelial differentiation ${ }^{21}$ and that p63-null mice developed a nontransitional default simple cubical epithelium. ${ }^{22}$ In addition, Signoretti et $\mathrm{al}^{23}$ reported that the urothelium of 18.5-day p63-null embryos contain a single layer that resembles umbrella cells and expresses uroplakin III (UPIII). We now report, by analyzing the histological and immunophenotypic features of the mucosa in p63-null mice, that it is constituted of exclusively umbrella cells.

Approximately $90 \%$ of malignant neoplasms that occur in the urinary bladder are of epithelial origin, ${ }^{24}$ and most of them correspond histologically to urothelial carcinomas (UCs). Because of a dearth of effective p63-specific antibodies, most reported studies have measured TP63 mRNA expression in human bladder tumors by RT-PCR using isoform-specific primers. ${ }^{22,25-27}$ The caveat of using this method is that one cannot be conclusive regarding protein expression levels. Previous studies dealing with p63 expression in bladder cancer reported that there was a correlation with tumor grade. ${ }^{22,27,28}$ Controversy has arisen from the analyses of $\Delta \mathrm{Np63}$ because some groups found that loss of $\Delta \mathrm{Np} 63$ was associated with an aggressive phenotype, ${ }^{29-31}$ whereas others have reported that $\Delta \mathrm{Np} 63$ overexpression could act as an oncogene in bladder cancer and other tumor types by promoting cell survival and proliferation. ${ }^{32-34}$ Moreover, $\Delta \mathrm{Np63}$ overexpression has also been reported in squamous cell carcinoma and linked to 3q27-29 genomic amplification, an amplicon that includes the TP63 gene. ${ }^{33,35}$

Using novel and commercially available anti-p63 isoform-specific antibodies, we analyzed the presence of different p63 variants expressed in the urothelium of mice during development, normal human urothelium, and different stages of human bladder cancer. Our results suggest a crucial role for the distinct expression of p63 isoforms in bladder tumor progression. Therefore, we propose a new categorization of invasive bladder cancer based on $\Delta$ Np63 expression, which has critical prognostic implications.

\section{Materials and Methods}

\section{Cell Culture and Transfections}

J82 invasive bladder cancer cell line was grown and maintained in minimal essential medium supplemented with $10 \%$ fetal bovine serum and $1 \%$ nonessential amino acids. Transfections were performed using this cell line because J82 cells do not express p63 intrinsically, ${ }^{22,24,25}$ with Lipofectamine 2000 reagent (Invitrogen Corp, Carlsbad, CA) in accordance with the manufacturer's protocols. Expression vectors derived from p3xFLAG-CMV-7.1 were TAp63 $\alpha$, TAp63 $\beta$, TAp63 $\gamma, \Delta$ Np63 $\alpha, \Delta$ Np63 $\beta, \Delta$ Np63 $\gamma$, and a backbone vector as a control.

\section{Antibodies and Immunoblotting}

To detect different isoforms of p63, we assembled a panel of antibodies that was further validated in tissue samples. These include mouse monoclonal anti-p63 [4A4 (SantaCruz Biotechnology Inc, Santa Cruz, CA)] to detect all p63 variants, rabbit polyclonal purified anti- $\Delta$ Np63, rabbit polyclonal anti-p63 $\alpha$ [H-129 (Santa-Cruz)], mouse monoclonal anti-p63 $\alpha$, mouse monoclonal anti-p63 $\alpha / \beta$, and anti-Flag (Sigma Aldrich Co., St. Louis, MO). Mouse (pantropic) monoclonal p53 antibody clone PAb1801 (CalbiochemEMD Chemicals, Gibbstown, NJ) was used to recognize p53, and a rabbit polyclonal actin antibody (Sigma) was used as a loading control for immunoblotting studies (see as follows). For immunoblotting, cells were washed twice with PBS and then collected in cold extraction buffer [10 $\mathrm{mmol} / \mathrm{L}$ Tris $(\mathrm{pH} 7.5), 1 \mathrm{mmol} / \mathrm{L}$ EDTA, $400 \mathrm{mmol} / \mathrm{L} \mathrm{NaCl}$, $10 \%$ glycerol, $0.5 \%$ NP40, $5 \mathrm{mmol} / \mathrm{L} \mathrm{NaF}, 1 \mathrm{mmol} / \mathrm{L}$ dithiothreitol, and $0.1 \mathrm{mmol} / \mathrm{L}$ phenylmethylsulfonyl fluoride] followed by centrifugation at $13,000 \times g$ for 10 minutes at $4^{\circ} \mathrm{C}$. Supernatants were resuspended in $6 \times$ protein sample buffer [30\% glycerol, 2M $\beta$-mercaptoethanol, 12\% SDS, 500 $\mathrm{mmol} / \mathrm{L}$ Tris ( $\mathrm{pH} \mathrm{6.8)}$, and $0.5 \mathrm{mg} / \mathrm{ml}$ of Bromophenol Blue] and boiled for 10 minutes at $95^{\circ} \mathrm{C}$. The samples were loaded onto SDS-polyacrylamide gels and transferred by a semi-dry transfer to nitrocellulose for 1 to 2 hours. SDSpolyacrylamide gel electrophoresis and immunoblotting procedures were conducted under standard conditions.

\section{Immunofluorescence in Cell Lines}

Cells were plated on coverslips in 60-mm culture dishes, and after 48 hours they were washed twice with PBS followed by incubation with $4 \%$ paraformaldehyde (Sigma) for 15 minutes. Cells were then washed three times with PBS, incubated with PBS/0.5\% Triton X-100 for $1 \frac{1}{2}$ minutes, and then blocked with $0.5 \%$ bovine serum albumin (Sigma) in PBS for 30 minutes at room temperature before the treatment with $50 \mu \mathrm{L}$ of the diluted primary antibodies (as described in the Antibodies and Immunoblotting section) for 1 hour at room temperature. The coverslips were then washed three times with PBS and double stained by incubation with $50 \mu \mathrm{L}$ of diluted (1:100) Alexa Fluor 594 donkey anti-mouse IgG antibody and Alexa Fluor 488 donkey antirabbit IgG secondary antibodies (Invitrogen) for 1 hour. Coverslips were then washed three times with PBS and mounted with Vectashield mounting medium containing DAPI. The immunofluorescence images were collected and analyzed using a Nikon Intensilight C-HGFI microscope (Nikon Gmbh, Dusseldorf, Germany) and SPOT Advanced software (SPOT Imaging, Sterling Heights, MI). 


\section{Immunohistochemistry and Immunofluorescence in Mouse and Human Tissues}

Immunohistochemical and immunofluorescence analyses were performed on formalin-fixed paraffin-embedded tissue sections from normal and p63-null mouse bladder samples. Normal human bladder and tissue microarrays built from superficial and invasive human bladder carcinomas (under institutional review board-approved protocols) were also used for the present study. We analyzed four tissue microarrays of 0.6-mm-diameter tissue cores arrayed in triplicate on a paraffin block. ${ }^{36}$ Tissue microarrays included tissues from 202 bladder cancer patients, distributed as follows: 147 non-muscle invasive UCs (31 pTa and 116 pT1) and 55 invasive UCs (22 pT2, 23 pT3, and 10 pT4). Follow-up clinical data for correlation with marker expression were available from 183 of the 202 bladder cancer patients included in this study. Pathological stage and grade of these 183 carcinomas were distributed as follows: 27 pTa carcinomas (20 low grade and 7 high grade), 109 pT1 highgrade carcinomas, 18 pT2 carcinomas, 20 pT3 carcinomas, and 9 pT4 carcinomas. We also studied 10 human normal bladder tissue samples from young patients with no history of bladder cancer $(n=3)$ and adjacent normal mucosa from patients with a diagnosis of bladder cancer $(n=7)$.

Immunohistochemical procedures were conducted using 5- $\mu \mathrm{m}$ deparaffinized tissue sections, submitted to antigen retrieval by steam treatment for 15 minutes in 10 $\mathrm{mmol} / \mathrm{L}$ citrate buffer ( $\mathrm{pH}$ 6.0). Slides were then treated with $10 \%$ normal serum for 30 minutes, followed by primary antibody (as described in the Antibodies and Immunoblotting section) incubation overnight at $4^{\circ} \mathrm{C}$. Antibodies specifically used for immunofluorescence in tissue samples include CK18 (rabbit polyclonal CK18, Abcam, Cambridge, MA), UPII (mouse monoclonal N-18, Santa Cruz), and CK5 (mouse monoclonal AF-138, Covance Inc, Princeton, NJ). Slides were then incubated with Alexa Fluor 488 and Alexa Fluor 594 IgG secondary antibodies (Invitrogen) for 30 minutes and were then mounted with Vectashield mounting medium containing DAPI. For enzyme-based immunohistochemistry, slides were incubated with biotinylated immunoglobulins for 30 minutes (Vector Laboratories Inc, Burlingame, CA) followed by avidin-biotin complexes (Vector Laboratories) for 30 minutes. Diaminobenzidine was used as chromogen and hematoxylin as the nuclear counterstain. The immunohistochemistry images were collected using a standard light microscope, and the immunofluorescence images were collected and analyzed using a Nikon microscope and SPOT Advanced software. A positive result for the different p63 isoforms or p53 was considered when more than $10 \%$ of the tumor cells displayed a nuclear expression of the protein by immunohistochemistry or immunofluorescence.

\section{Mice Procedures}

Mice used in this study were wild-type strain C57BL6 and p63-null strain B6.129S7-Trp63 (Jackson Laboratories, Bar Harbor, ME). All procedures were performed in accordance with the guidelines of the Institutional Animal Care and Use Committee. After sacrifice, bladders were removed and fixed in 10\% buffered formalin for further paraffin embedding and immunostaining.

\section{Statistical Analysis}

A total of 202 patients diagnosed as having bladder cancer were included in this study for analysis of the association among p63 isoforms, p53, and clinicopathological variables. The associations of protein expression patterns with overall, disease-free, and recurrence-free survival, defined as the time elapsed between the date of diagnosis and last follow-up date or progression date, respectively, were assessed in 183 patients from whom all required data were available. The log-rank test and survival curves were plotted using the standard KaplanMeier method. Significant associations among different antibodies were assessed using $\chi^{2}$ test and Fisher's $t$-test. $P<0.05$ was considered statistically significant. Statistical analyses were performed using SPSS v16.0 software (SPSS Inc, Chicago, IL).

\section{Results}

\section{Validation of a Novel Panel of p63 Isoform-Specific Antibodies}

To investigate the expression of specific p63 protein isoforms, we first evaluated a panel of anti-p63 antibodies for their specificity. We transfected J82, a bladder cancer cell line from an invasive UC lacking detectable levels of p63 protein, with TAp63 $\alpha$, TAp63 $\beta$, TAp63 $\gamma, \Delta N p 63 \alpha$, $\Delta N p 63 \beta$, or $\Delta N p 63 \gamma$ and a control backbone vector. Several isoform-specific p63 antibodies were tested by both immunoblotting and immunofluorescence assays, including newly generated $\Delta \mathrm{Np} 63, \mathrm{p} 63 \alpha$, and $\mathrm{p} 63 \alpha / \beta$ antibodies (Figure 1). Schematic illustration of p63 variants showing the transactivation domain, DNA binding domain, oligomerization domain, sterile $\alpha$ motif, and the antibodies that recognize the indicated p63 isoforms are shown in Figure 1A. Expression of TAp63 $\beta$ was substantially low; therefore, we detected a weaker band of this isoform probing with anti-Flag, p63 (4A4), and p63 $\alpha / \beta$ antibodies (Figure 1B). As previously reported, p63 protein expression was localized to the nucleoplasm of the transfected cells ${ }^{4,26}$ (Figure 1C). To date, we have not been able to generate a TAp63-specific antibody. Therefore, for the purpose of this study, we assume that the TAp63 isoform is expressed when a nuclear positivity is observed with the total p63 antibody (4A4), but there is no $\Delta$ Np63 expression.

\section{TAp63 and $\Delta$ Np63 Counterbalance Is Important for Urothelium Development}

To investigate the expression of p63 during urothelial development, we designed a strategy that allowed the analysis of protein levels of p63 variants in wild-type mice during ${ }^{18}$ embryogenesis, as well as in newborn and adult mice. Mouse urothelium displays histological features similar to human urothelium despite having only up to three layers in the mucosa, ${ }^{19}$ which comprise a basal, an 
A

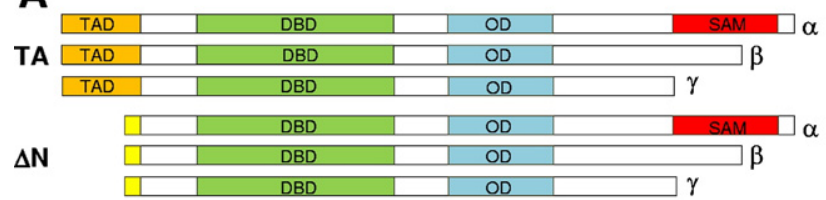

Flag p63(4A4) $\quad \Delta \mathrm{N} \quad \alpha \quad \alpha / \beta$

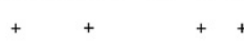

$+\quad+$

$++$

$\begin{array}{lllll}+ & + & + & + & + \\ + & + & + & & +\end{array}$

\section{B}

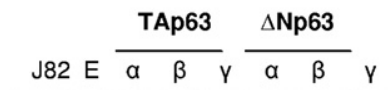

Anti-Flag

p63 (4A4)

$\Delta$ Np63

$\mathrm{p} 63 \mathrm{a}(\mathrm{H}-129)$

p63a
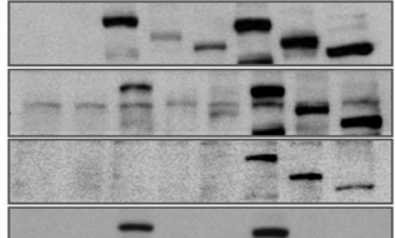

$p 63 \alpha / \beta$

actin

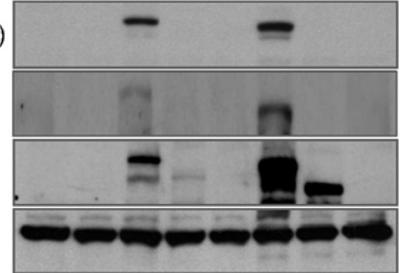

C

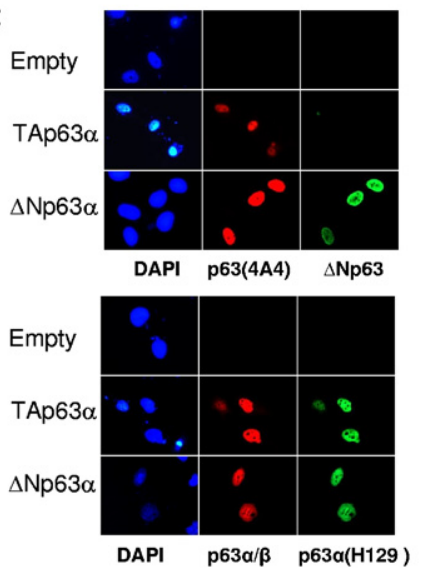

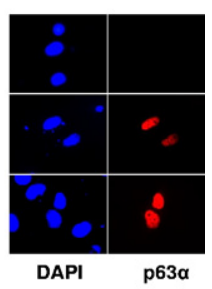

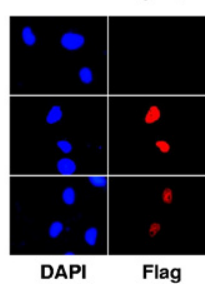

Figure 1. Characterization and validation of p63 isoform-specific antibodies. A: Schematic diagram of p63 variants showing the transactivation domain, DNA binding domain, oligomerization domain, and sterile $\alpha$ motif. The antibodies recognize the indicated p63 isoforms. B: Immunoblot analysis of transiently transfected p63 isoforms in the J82 cell line using anti-Flag, monoclonal anti-p63 (4A4), purified polyclonal anti- $\Delta \mathrm{Np} 63$ polyclonal anti-p63 $\alpha$ (H129), monoclonal anti-p $63 \alpha$, monoclonal anti-p $63 \alpha / \beta$, and actin as a loading control. C: Coimmunostaining for p63 variants was performed using $\Delta \mathrm{Np} 63$ and $4 \mathrm{~A} 4$ antibodies, $\mathrm{p} 63 \alpha(\mathrm{H} 129)$ and $\mathrm{p} 63 \alpha / \beta$ antibodies, and p $63 \alpha$-specific and anti-Flag antibodies. Original magnification, $\times 400$. intermediate, and a superficial layer of umbrella cells. Basal and intermediate urothelial cells displayed nuclear positivity for all p63 antibodies analyzed, which validated the use of these antibodies in mouse tissue samples (Figure 2A). It was of interest to assess which p63 isoforms were implicated during embryogenesis and urothelial development. We were surprised to discover that the first isoform to be expressed was TAp63 because it could be detected in urothelium as early as at the embryonic age of 16.5 days (Figure 2B). Only later after birth, approximately 24 hours after delivery, did we detect expression of $\Delta$ Np63. Furthermore, we observed distinct expression of p63 $\alpha$ before and after birth, indicating that the first isoform to be expressed is actually TAp63 $\alpha$ (Figure 2C). We cannot rule out the existence of $\Delta \mathrm{Np63}$ protein below the levels of detection by the antibody during embryogenesis. However, even if that was the case, its level of expression significantly increased after birth to reach adult mice concentration. These results are in agreement with a previous report by Koster et $\mathrm{al}^{18}$ in which they described that TAp63 isoforms are the first to be expressed during embryogenesis and that they are essential for the initiation of the epithelial stratification process in skin epidermis.

\section{p63-Null Mice Develop an Abnormal Bladder Urothelium Constituted of Solely Umbrella Cells}

The p63-null mice die a few hours after birth from severe malformation of their skin and other organs and dehydration. 5,6,13 Our group previously reported that p63-null mice develop a bladder but that the urothelium was composed of a single cell layer. ${ }^{22}$ Furthermore, Signoretti et $\mathrm{al}^{23}$ demonstrated that the urothelium of 18.5-day p63null embryos contain a single layer of cells characterized by expression of UPIII. We now report that this layer is composed of exclusively umbrella cells and that the basal and intermediate urothelial layers are missing in the bladders of these mice (Figure 3). Immunofluorescence analysis showed that CK18 and UPII were expressed in cells of this unique urothelial layer generated in p63-null mice bladder, a phenotype shared with umbrella cells of wild-type bladder urothelium (Figure 3, A and B, two upper panels). On the contrary, the high molecular weight CK5 was present in the basal and intermediate urothelial cell layers of wild-type mice, whereas p63null mice urothelium lacked expression of CK5 (Figure $3 \mathrm{~B}$, two lower panels). Thus, these results confirm that the single urothelial layer observed in p63-null mice is formed by cells with an umbrella cell phenotype.

\section{p63 Isoform Expression in Normal Human Urothelium}

To gain further insight into the expression of TA and $\Delta$ Np63 isoforms in normal bladder, we analyzed 10 different tissue samples of normal human bladder by both enzyme-based immunohistochemistry and immunofluorescence. As expected, basal and intermediate urothelial cells displayed an intense and homogeneous nuclear total p63 expression, which corresponded to p63 $\alpha$ and possibly p63 $\beta$ isoforms (Figure 4A), and it was excluded from the superficial layer as confirmed by CK18 co-immunostaining (Figure 4B, upper row). $\Delta$ Np63 was not detected by either method (Figure 4, lower row, and Table 1); thus, we concluded that TAp63 $\alpha$ and possibly TAp63 $\beta$ are the main isoforms expressed in normal human bladder urothelium. At present, we do not fully comprehend the reason for the differences between the expression of p63 isoforms in human and mouse samples assayed. One possible explanation could be that the levels of expression of $\Delta \mathrm{Np63}$ in human urothelium are below the limit of detection of the $\Delta \mathrm{Np63}$ antibody used in this study. 
A
$\Delta \mathrm{Np63}$

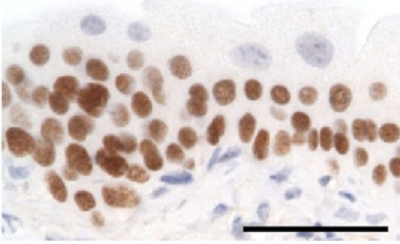

B

embryo-16.5 days

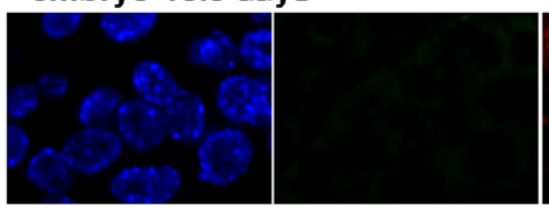

embryo-19.5 days

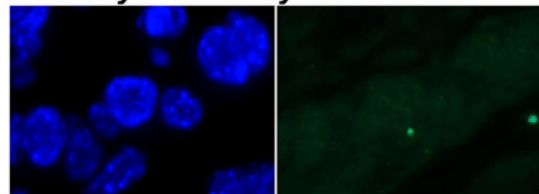

6 hours

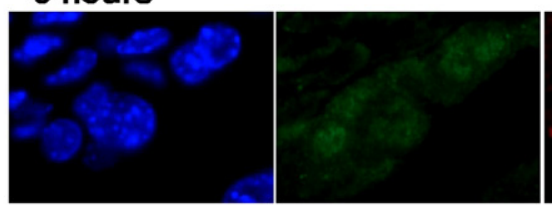

24 hours

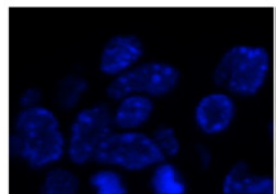

DAPI

C

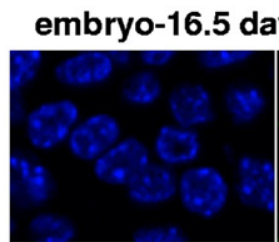

DAPI

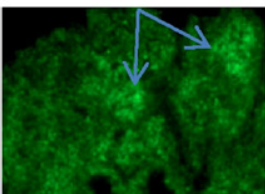

$\Delta \mathrm{Np63}$
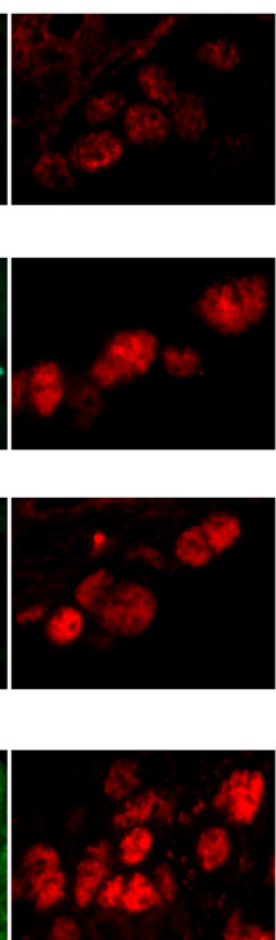

p63 (4A4)

\section{2 days}

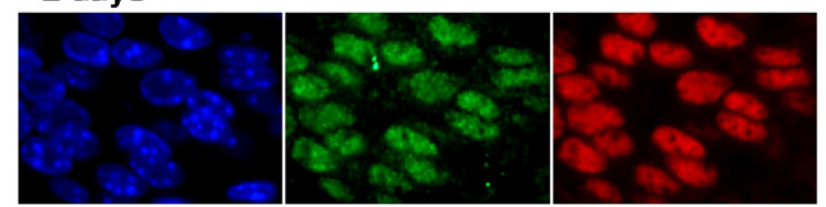

\section{5 days}
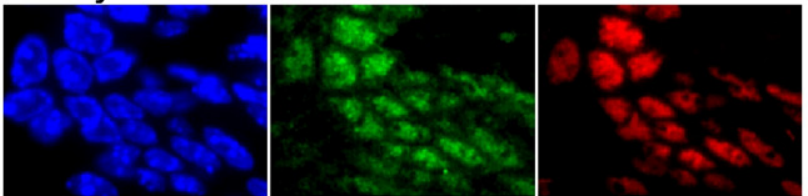

7 days
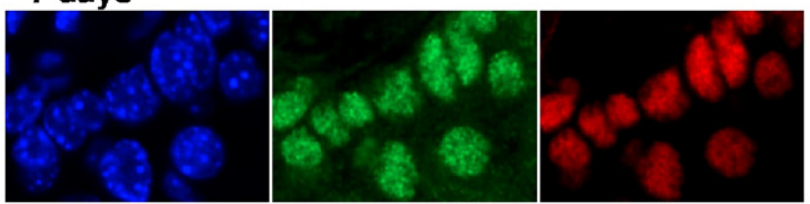

14 days
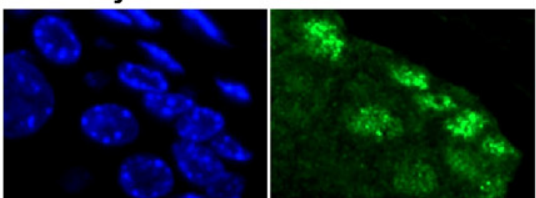

$\Delta$ Np63

DAPI

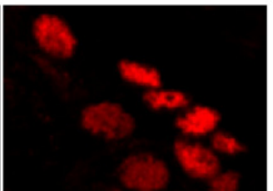

p63 (4A4) $p 63 \alpha / \beta$

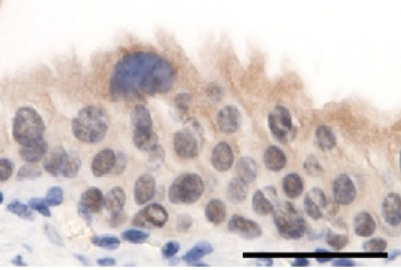

7 days

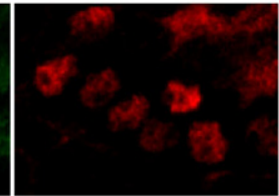

$p 63 \alpha / \beta$

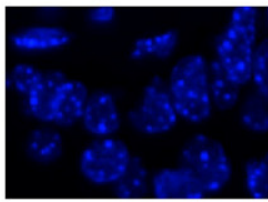

DAPI

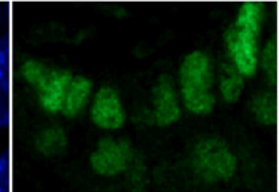

p63a (H129)

Figure 2. Differential expression of p63 isoforms during urothelium development. A: Validation of $4 \mathrm{~A} 4, \Delta \mathrm{Np} 63$, p63 $\alpha$, and p $63 \alpha / \beta$ antibodies in adult mouse bladder urothelium by immunohistochemistry. B: Immunofluorescence analysis of $\Delta \mathrm{Np} 63$ and $4 \mathrm{~A} 4$ antibodies at various developmental time points. $\Delta \mathrm{Np} 63$ expression is detected only after 24 hours of birth, whereas TAp63 variant is detected during embryogenesis. Blue arrows point to two urothelial cells displaying nuclear expression of $\Delta \mathrm{Np} 63$. C: $\mathrm{p} 63 \alpha(\mathrm{H} 129)$ and $\mathrm{p} 63 \alpha / \beta$ antibodies staining at two different time points as designated. Scale bar $=100 \mu \mathrm{m}$.

\section{$\Delta$ Np63 and Mutant p53 Are Associated with Bladder Cancer Tumor Progression}

Next we explored which p63 isoforms are expressed in human urothelial bladder cancer and whether there was a difference between the expression profile in normal bladder urothelium and bladder tumors (Figure 5). We analyzed 202 UCs of the bladder and 10 normal urothelium samples. Both non-muscle invasive (divided into two tumor stages: pTa and pT1) and invasive (including all tumor stages higher than pT2 and identified as pT2+) human bladder carcinomas were included in this study to better discern different patterns of p63 isoforms expression during tumor progression. Both pTa and pT1 carcinomas displayed high nuclear expression of total p63 with no significant differences between these two stages or even with normal bladder urothelium $(96.8 \%$ of the pTa cases 

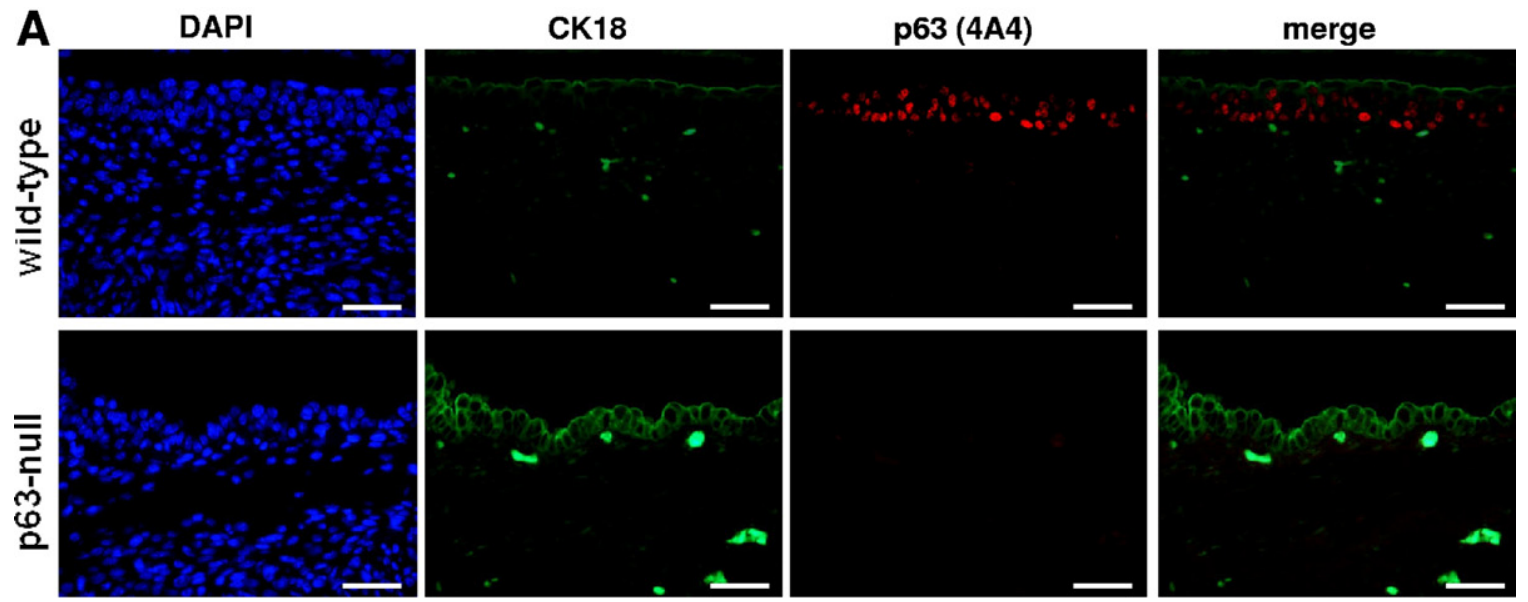

B

DAPI
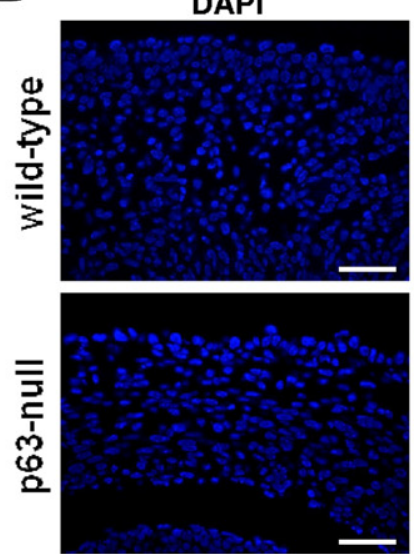

DAPI
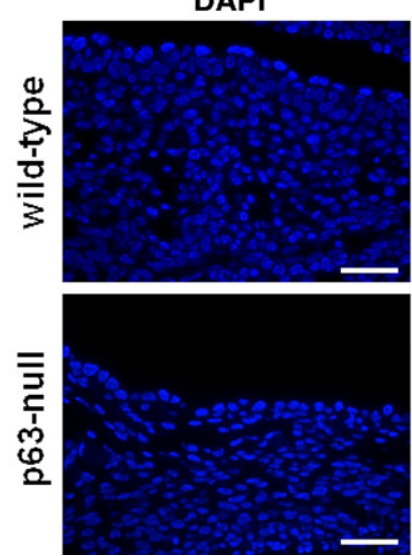

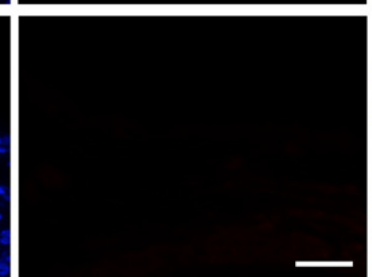

UPII
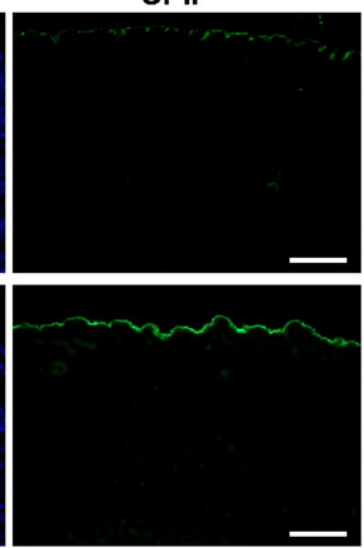

CK5
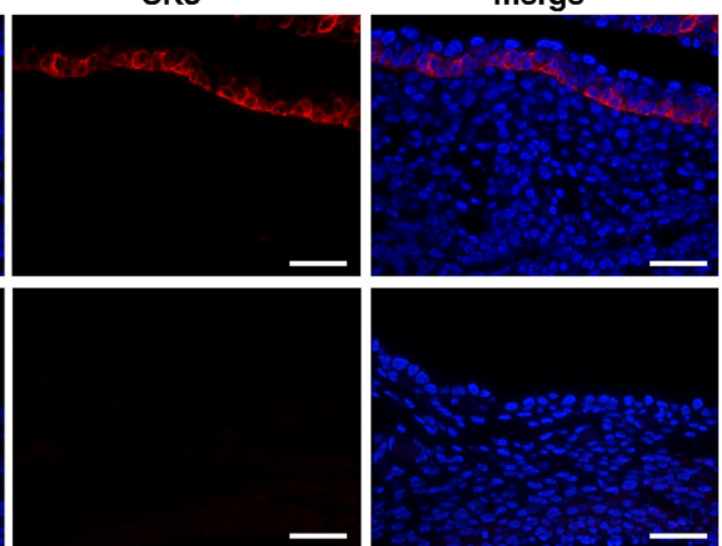

merge
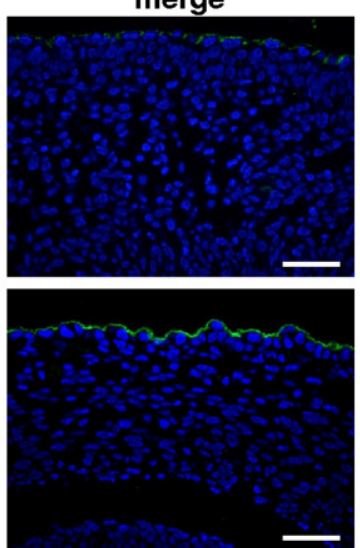

merge

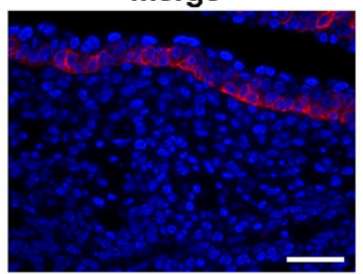
is detected only in umbrella cells. B: Immunofluorescence analysis of UPII (two upper panels) and CK5 (two lower panels) in representative wild-type and p63-null mice. p63-null urothelium is composed of cells displaying a UPII-positive phenotype and lacking expression of CK5, consistent with an umbrella cell phenotype. Scale bar $=100 \mu \mathrm{m}$.

Figure 3. The p63-null mice generate a singlelayered urothelium displaying an umbrella cell phenotype. A: Immunofluorescence analysis of a representative urothelium from a wild-type p63 mouse showing that p63 is expressed in the basal and intermediate layers, whereas umbrell

$$
\text { type. scale bar }=100 \mu \mathrm{m} \text {. }
$$

showed expression of total p63, 94.0\% of the pT1 cases, and $100 \%$ of normal urothelium cases; Figure $5 \mathrm{~A}$ and Table 1). However, we observed significant differences with respect to the expression of $\Delta \mathrm{Np} 63, \mathrm{p} 63 \alpha$, and TAp63 among the two non-muscle invasive stages. $\Delta \mathrm{Np} 63$ was undetectable in normal bladder urothelium, whereas it was expressed in $29 \%$ of the pTa and $17.2 \%$ of the pT1 bladder tumors. On the contrary, p63 $\alpha$ was expressed in $80 \%$ of normal urothelium, $48.4 \%$ of pTa, and $55.2 \%$ of pT1 tumors. Moreover, p53 protein expression levels, which are undetectable in normal bladder, were significantly lower in pTa tumors (6.5\%) when compared with
pT1 tumors (24.1\%). Next we evaluated the expression of p63 isoforms in invasive (stages pT2-pT4) bladder tumor samples. Total p63 was detected in $69.1 \%$ of the cases, $\Delta$ Np63 in $41.8 \%$ of the cases, p63 $\alpha$ in $38.2 \%$ of the cases (Figure $5 \mathrm{~B}$ and Table 1), and p53 in $43.6 \%$ of the cases (Table 1). Taken together, total p63 and p63 $\alpha$ expression levels were significantly lower in invasive carcinomas when compared with nonmuscle invasive tumors (69.1\% versus $94.6 \%$ and $38.2 \%$ versus $52.3 \%$, respectively). On the contrary, $\Delta N p 63$ protein levels showed the opposite trend: $41.8 \%$ of invasive carcinomas displayed a positive phenotype, whereas only $19.7 \%$ of 
A
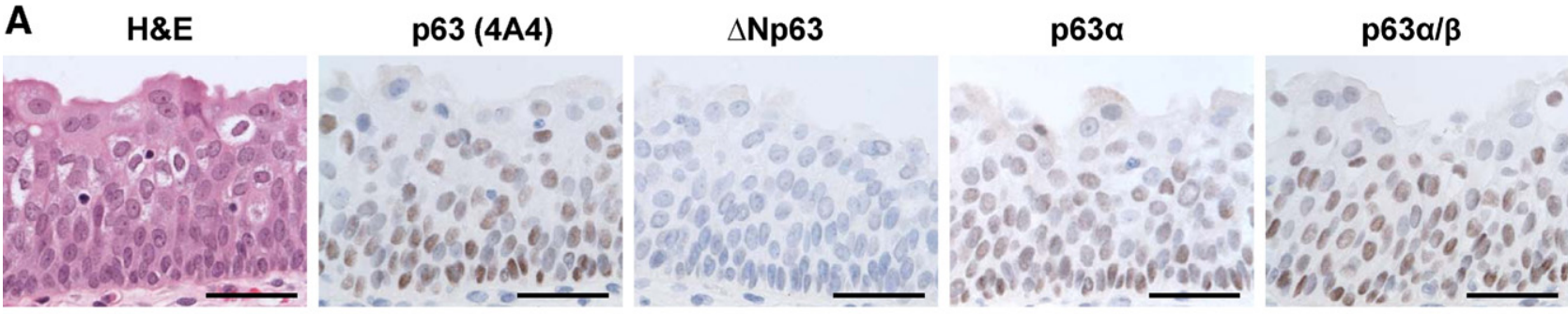

B
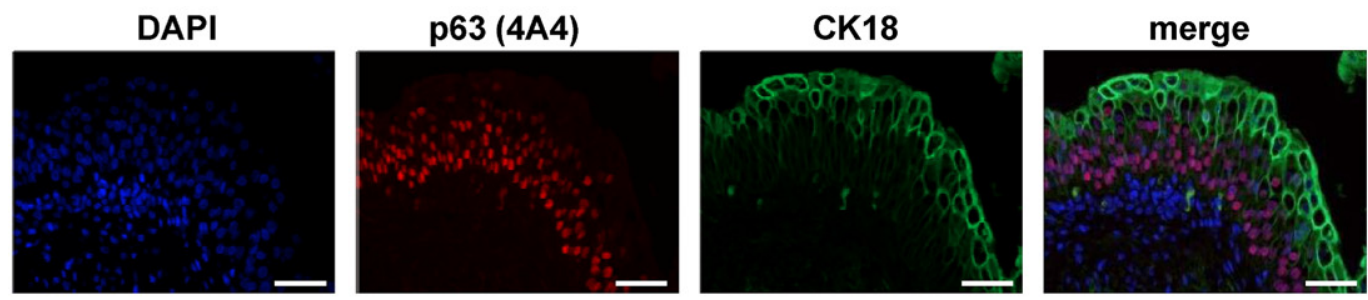

DAPI

p63 (4A4)
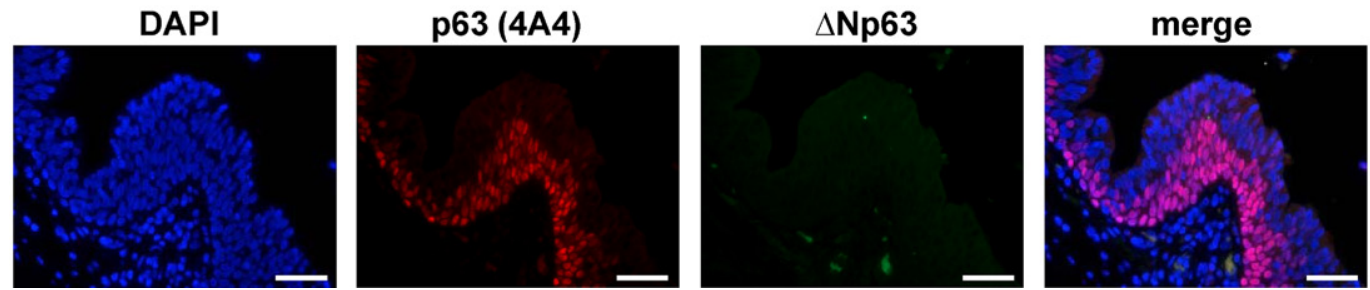

Figure 4. Differential expression of $\mathrm{p} 63$ isoforms in human normal bladder urothelium. A: Validation of $4 \mathrm{~A} 4, \Delta \mathrm{Np} 63$, p63 $\alpha$, and p $63 \alpha / \beta$ antibodies in human bladder urothelium by immunohistochemistry. B: Immunofluorescence analysis of CK18 and total p63 shows that p63 is expressed in the basal and intermediate layers of urothelium, whereas umbrella cells display a p63-negative phenotype. Scale bar $=100 \mu \mathrm{m}$.

the non-muscle invasive cancers showed expression of $\Delta$ Np63. Moreover and as expected, p53 expression levels, which are known to correlate with mutated TP53, ${ }^{37,38}$ were also significantly higher in the invasive tumors when compared with non-muscle invasive neoplasms (43.6\% vs 20.4\%). Thus, these results highlight the importance of determining which p63 isoforms are expressed in the distinct bladder cancer stages because total p63 evaluation may lead to erroneous conclusions.

\section{$\Delta$ Np63 Expression Has Significant Clinical Implications for Patients with Invasive Bladder Cancer}

In view of the fact that we detected differences in the expression levels of p63 isoforms among distinct bladder cancer stages, we were intrigued to investigate its poten- tial clinical implications as a prognostic factor. We studied the association of p63 variants with clinical outcome in 183 of the 202 patients of this study. In the whole cohort of patients, we observed that patients whose tumors displayed a total p63-positive phenotype had a better prognosis than those with tumors that had a p63-negative phenotype. The median \pm SD disease-specific survival for patients with p63-negative tumors was $38.0 \pm 11.7$ months, whereas patients with p63-positive tumors did not reach median survival after 160 months of follow-up $(P<0.0001$; Figure 6A). Because the total p63 expression correlated with tumor stage in our cohort, and bladder cancer is a heterogeneous disease constituted of non-muscle invasive and invasive tumors with a different nature, we next evaluated the clinical implications of p63 expression in these two groups of patients separately. We analyzed papillary pTa and pT1 non-muscle invasive

Table 1. Expression of p63 Isoforms and p53 in Bladder Tissues

\begin{tabular}{|c|c|c|c|c|c|c|}
\hline \multirow[b]{2}{*}{ Proteins/isoforms } & \multicolumn{5}{|c|}{ No. of patients (\% of expression of specific proteins) } & \multirow{2}{*}{$\begin{array}{l}\text { Total no. } \\
\text { of cases }\end{array}$} \\
\hline & p63 (total) & TA p63 & $\Delta \mathrm{N}$ p63 & $\mathrm{p} 63 \alpha$ & p53 & \\
\hline Normal bladder & $10(100)$ & $10(100)$ & $0(0)$ & $8(80)$ & $0(0)$ & 10 \\
\hline Noninvasive pTa UC & $30(96.8)$ & $21-30(67.7-96.8)$ & $9(29)$ & $15(48.4)$ & $2(6.5)$ & 31 \\
\hline Noninvasive pT1 UC & $109(94.0)$ & $91-109(78.4-94.0)$ & $20(17.2)$ & $62(55.2)$ & $28(24.1)$ & 116 \\
\hline Total noninvasive UC & $139(94.6)$ & $112-139(76.1-94.6)$ & $29(19.7)$ & $77(52.3)$ & $30(20.4)$ & 147 \\
\hline $\mathrm{pT}^{+} \mathrm{UC}$ & $38(69.1)$ & $17-38(30.9-69.1)$ & $23(41.8)$ & $21(38.2)$ & $24(43.6)$ & 55 \\
\hline$P$ value* & $<0.0001$ & $<0.0001$ & $<0.001$ & $<0.01$ & $<0.0001$ & 212 \\
\hline
\end{tabular}

${ }^{*} P$ values were measured by Pearson's $\chi^{2}$ test. 


\section{A Noninvasive Bladder Cancer}
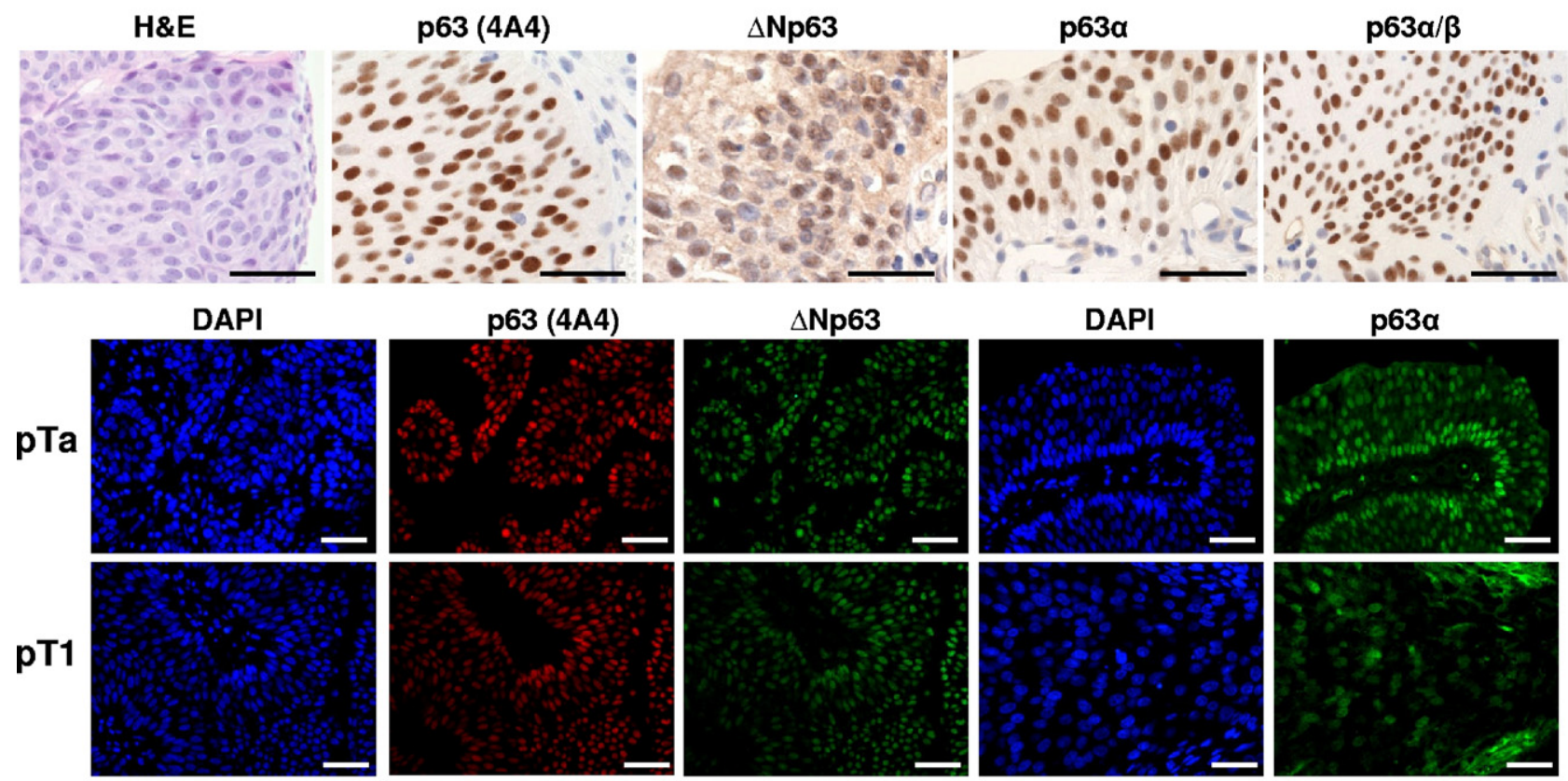

B

\section{Invasive Bladder Cancer}
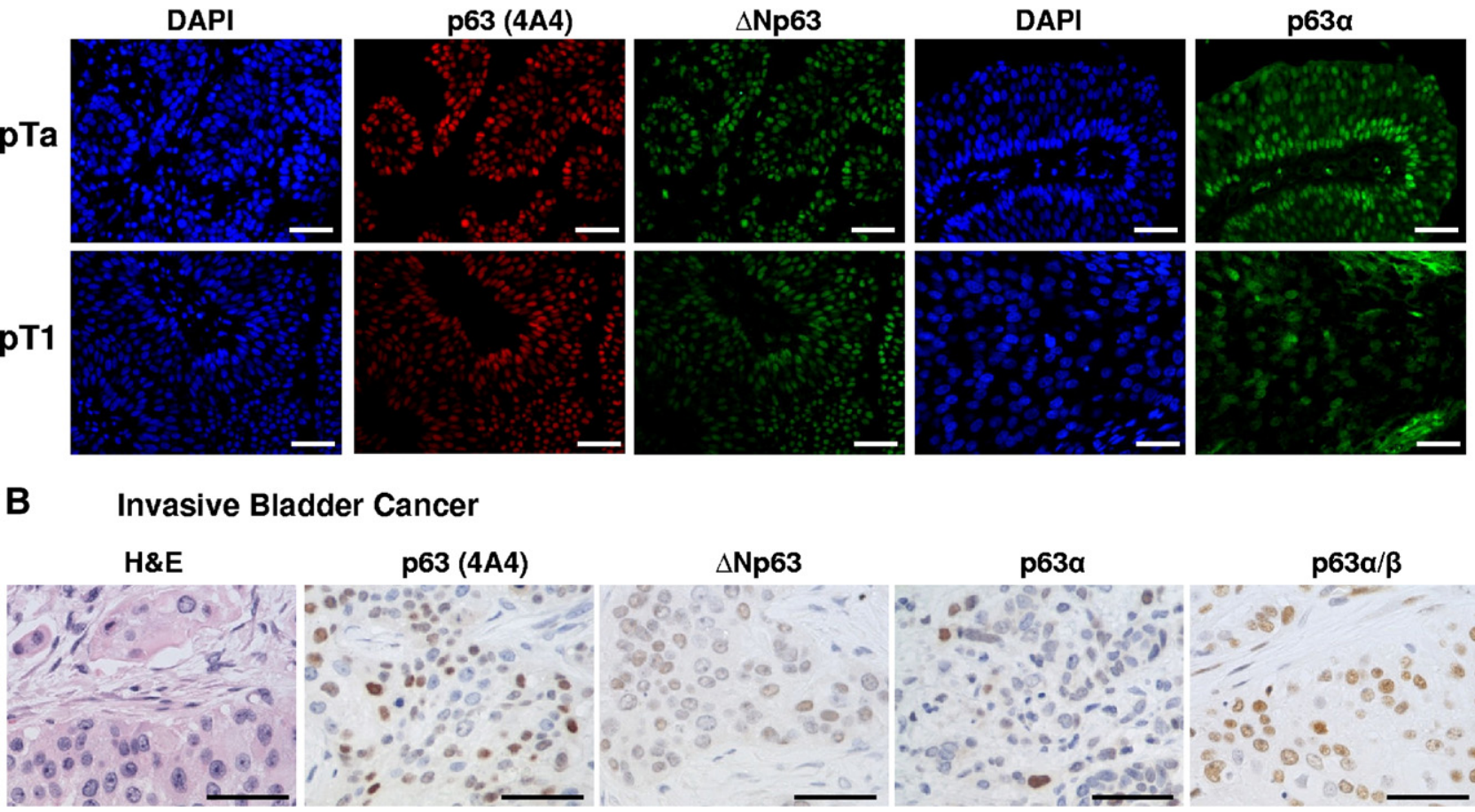

\section{DAPI}
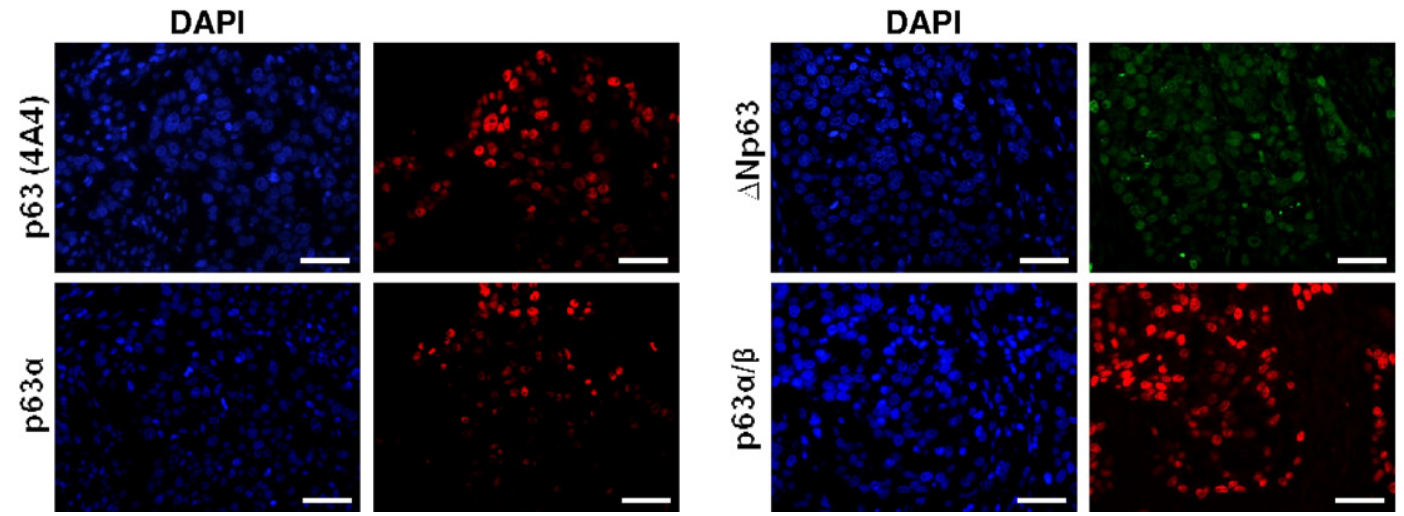

Figure 5. Distinct p63 isoforms are expressed in both non-muscle invasive and invasive bladder cancer. A: Immunohistochemistry (upper row) and immunofluorescence (lower panels) analyses of p63 variants expression in representative non-muscle invasive bladder cancer samples using different p63 isoformspecific antibodies. B: Immunohistochemistry (upper row) and immunofluorescence (lower panels) analyses of p63 variants expression in representative invasive bladder cancer samples using different p63 isoform-specific antibodies. Scale bar $=100 \mu \mathrm{m}$.

tumors together for statistical purposes, because from the clinical point of view they are both considered superficial carcinomas. Only in non-muscle invasive carcinomas did total p63 expression show significant prognostic connotations ( $P<0.05$; Figure $6 \mathrm{~B}$ ). Most non-muscle invasive carcinomas $(94.6 \%)$ are characterized by a p63-positive phenotype, but the few that display a p63- negative phenotype show a higher recurrence rate, with a median $\pm \mathrm{SD}$ recurrence-free survival time of $16 \pm$ 1.3 months compared with the $53 \pm 1.7$ months of the p63-positive cases. Regarding different p63 isoforms, the same trend was observed in non-muscle invasive carcinomas with $\Delta \mathrm{Np63}$. Tumors with a $\Delta$ Np63-negative phenotype showed a higher recurrence rate than 
A
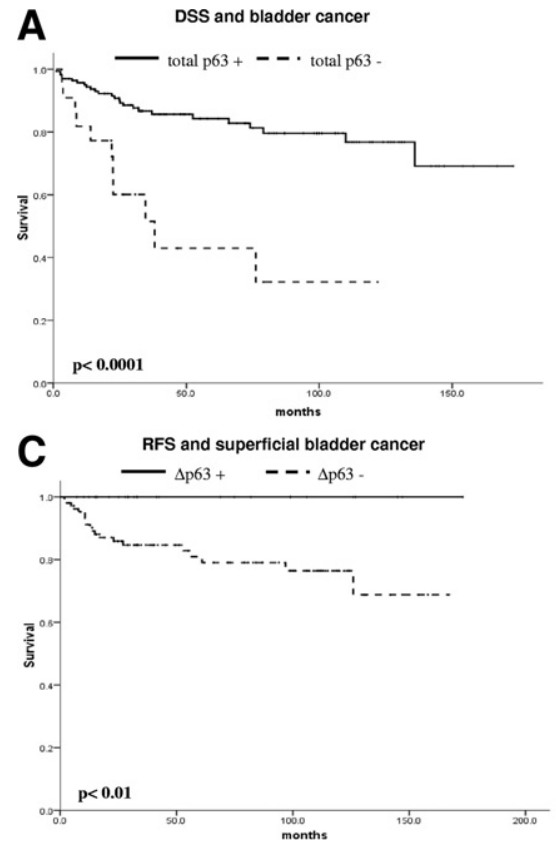

B

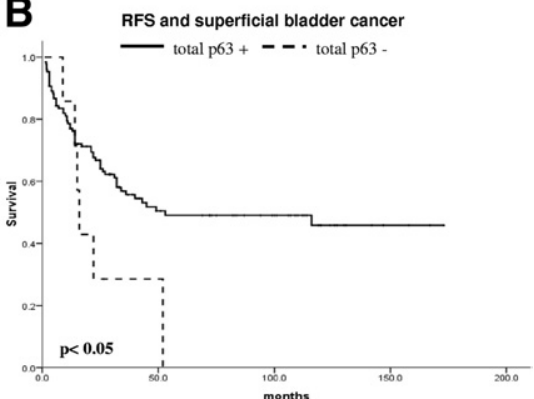

D

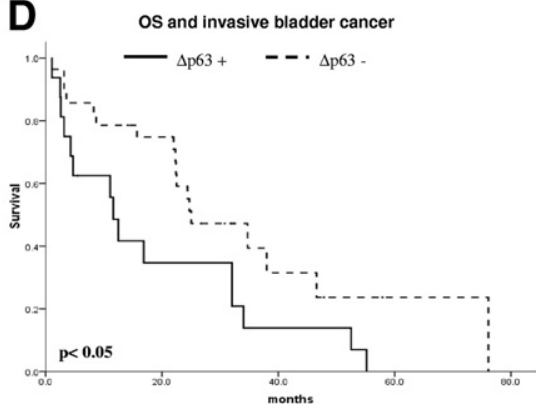

Figure 6. Expression of p63 isoforms is associated with clinical outcome in bladder cancer patients. A: Disease-specific survival (DSS) and total p63 expression in the complete bladder cancer cohort of patients included in this study. B: Recurrence-free survival (RFS) and total p63 expression in patients with superficial bladder cancer. C: RFS and $\Delta \mathrm{Np} 63$ expression in patients with superficial bladder cancer. D: Overall survival (OS) and $\Delta \mathrm{Np} 63$ expression in patients with invasive bladder cancer. those with a $\Delta$ Np63-positive phenotype $(P<0.01$; Figure $6 \mathrm{C}$ ). Although $\Delta \mathrm{Np63}$ could not predict diseasespecific survival in non-muscle invasive bladder cancer patients, median $\pm \mathrm{SD}$ disease-free survival of patients with a $\Delta$ Np63-negative phenotype was $16.9 \pm 14.7$ months compared with $34.7 \pm 8.7$ months in patients whose tumors displayed a $\Delta$ Np63-positive phenotype $(P=$ 0.09; data not shown). Strikingly, and opposite to the results observed with non-muscle invasive bladder tumors, we found that $\Delta \mathrm{Np} 63$ may be a marker of poor prognosis for a subset of patients affected by invasive carcinoma, because patients whose tumors showed a $\Delta$ Np63-positive phenotype had shorter survival than those with a $\Delta$ Np63-negative phenotype $(P<0.05$; Figure $6 \mathrm{D})$. Median $\pm \mathrm{SD}$ overall survival of $\Delta \mathrm{Np63-posi-}$ tive phenotype cases was $11.6 \pm 1.3$ months, whereas patients with a $\Delta$ Np63-negative phenotype tumors had a median $\pm \mathrm{SD}$ survival of $25 \pm 6.4$ months. This finding could explain the observation that total p63 is not a good prognostic marker for invasive bladder cancer because detection of the protein could be due to the presence of either TAp63 or $\Delta \mathrm{Np} 63$, which clearly show opposite clinical implications in our cohort of patients. Finally, because of the novelty of this finding in invasive bladder cancer, we analyzed whether such a phenotype was associated with a specific basal-like or luminal-like CK phenotype. Nineteen of the 45 invasive bladder cancer tissue samples (42.2\%) analyzed displayed a $\Delta$ Np63-negative phenotype, and among these 18 tumors (94.7\%) did not express high molecular weight CKs, such as CK5 and CK10 $(P<$ $0.01)$, whereas $15(78.9 \%)$ of the tumors showed an intense CK20 expression $(P<0.05)$. Thus, these results identify two distinct subsets of invasive bladder cancer with prognostic implications: a basal-like cell phenotype characterized by expression of both $\Delta$ Np63 and high molecular weight CKs with poor prognosis and a luminal-like cell phenotype with lack of $\Delta \mathrm{Np} 63$ and expression of CK20 displaying a more favorable clinical outcome (Figure 7).

\section{Discussion}

The present study reports for the first time the ability to differentiate between p63 isoforms at the protein level

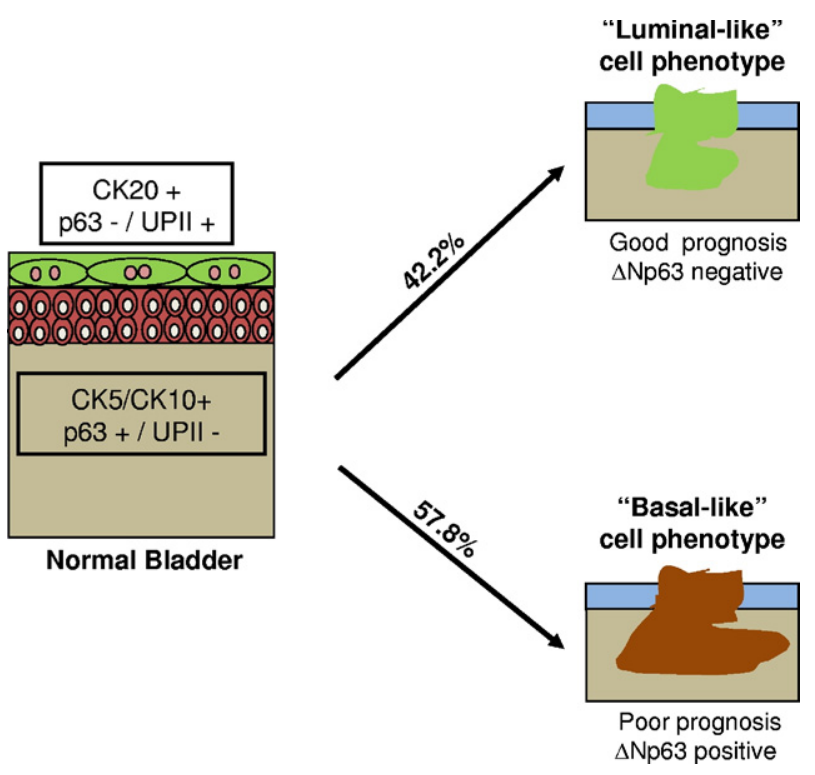

Figure 7. Schematic representation of a proposed novel categorization of invasive bladder carcinomas. It is our theory, based on $\Delta \mathrm{Np} 63$ and $\mathrm{CK}$ expression, that bladder cancer could be categorized into two subtypes: (1) basal-like phenotype displaying $\Delta \mathrm{Np} 63$ and high molecular weight CKs (CK5 and CK10), but lacking low molecular weight CKs, such as CK20 and (2) luminal-like phenotype displaying CK20 but lacking $\Delta$ Np63 and CK5. Basal-like invasive bladder carcinomas were found in this study to be associated with a poor clinical outcome when compared with luminallike tumors. 
using a novel panel of well-characterized antibodies, including newly generated monoclonal and polyclonal antibodies. This study also highlights the relevance of distinct p63 isoform expression patterns in the context of urothelial development, urothelial bladder cancer progression, and their clinical significance regarding prognosis for patients affected by bladder cancer, mainly based on $\Delta$ Np63 expression.

The present study reveals that p63 is expressed in the cells of both basal and intermediate layers of human and mouse normal bladder urothelium. Significantly, we observed that umbrella cells in the superficial, luminal layer display a p63-negative phenotype. Regarding urothelial development, analysis of murine fetal and newborn bladders revealed that the first and most expressed isoform is TAp63 $\alpha$, appearing as early as 16.5 days of embryonic age. Only 24 hours after birth we could detect $\Delta$ Np63 expression in the basal and intermediate layers of the normal mouse urothelium. These data point to the important role of balancing p63 isoform expression during urothelial development. These results are in agreement with previously published data in a skin model, which revealed TAp63 isoform protein as a crucial regulator for the initiation of epithelial stratification in the epidermis, requiring the counterbalance of $\Delta \mathrm{Np} 63$ to terminate the differentiation program. ${ }^{18}$ Critical studies that could further characterize such observations would require the generation of p63 isoform-specific knockouts, which in turn would better define the sequence of events during urothelial development and differentiation processes.

This study also reports that p63-null mice develop an abnormal bladder epithelial mucosa composed of a single-cell layer with an umbrella cell phenotype. It was previously shown that this layer of 18.5-day p63-null embryos stained for UPIII. ${ }^{23}$ We now demonstrate that this default mucosa is characterized by expression of UPII and low-molecular-weight CKs, such as CK18, while lacking high-molecular-weight $\mathrm{CKs}$, including $\mathrm{CK} 5$ and CK14, a phenotype we refer to as luminal-like. These results validate our working hypothesis that umbrella cells may not represent terminally differentiated cells generated from the basal and intermediate cell layers of the urothelium, but instead could derive from either an alternative differentiation pathway or a distinct epithelial stem cell. ${ }^{19}$ Further studies aimed at identifying these urothelial stem cells are mandatory to better understand urothelial physiology and the generation of such a special pseudostratified epithelium.

Expansion of these studies into mechanisms of bladder cancer progression revealed that expression of total p63, $\Delta \mathrm{Np} 63 \alpha$, and mutant p53 proteins were significantly associated with UC tumor stage. Moreover, we found that the $\Delta N p 63$ phenotype has a significant impact on the clinical outcome of patients affected with invasive bladder cancer. In accordance with previous reports, we observed that total p63 expression was associated with a good prognosis when analyzing the entire cohort of patients or patients affected with non-muscle invasive bladder neoplasms. The same trend as total p63 was observed for $\Delta \mathrm{Np63}$ in patients with non-muscle invasive bladder cancer because a $\Delta$ Np63-positive phenotype was associated with a better outcome (longer recurrence-free survival and disease-free survival) when compared with patients with a $\Delta$ Np63-negative tumor. However, $\Delta$ Np63 expression defined a subset of invasive tumors with an aggressive clinical course and shorter survival. These findings could be explained by the fact that $\Delta$ Np63 has been reported to function as an oncogene $e^{32-34}$ because its genomic structure is part of a $3 q 27-29$ amplicon and the protein is overexpressed in certain invasive tumors with squamous cell differentiation. ${ }^{33,35,39}$ This issue is supported by the fact that in our study we have observed that $\Delta N p 63$ expression is directly associated with expression of high molecular weight CKs, characteristic of squamous cell carcinomas. Invasive UCs with a $\Delta$ Np63-positive phenotype display what we have designated as a basal-like cell phenotype, which is characterized by the expression of CK5 and the lack of CK20 and associated with a shorter disease-free survival when compared with invasive bladder carcinomas displaying a luminal-like phenotype. Alternatively, $\Delta$ Np63 could act as a nonamplified but dominant-negative effector protein when overexpressed at hyperphysiological levels, a phenomenon that has also been described ${ }^{5,6}$ and could explain the poor prognosis ascribed to patients with $\Delta$ Np63-positive invasive bladder carcinomas. Altogether, these results highlight the importance of a balance among the different p63 isoforms during urothelial development and bladder cancer progression.

\section{Acknowledgments}

We are grateful to all of the members of the CordonCardo laboratory, mainly to Dr. Jun Yan for excellent suggestions. We thank Dr. Ella Fraulich, Tulio Matos, and Paul Eric Macias for technical assistance and Dr. Nicole Baptiste and Dr. Maria Lokshin for critical reading.

\section{References}

1. Augustin M, Bamberger C, Paul D, Schmale H: Cloning and chromosomal mapping of the human p53-related KET gene to chromosome $3 q 27$ and its murine homolog Ket to mouse chromosome 16. Mamm Genome 1998, 9:899-902

2. Osada M, Ohba M, Kawahara C, Ishioka C, Kanamaru R, Katoh I, Ikawa $Y$, Nimura $Y$, Nakagawara A, Obinata M, Ikawa S: Cloning and functional analysis of human p51, which structurally and functionally resembles p53. Nat Med 1998, 4:839-843

3. Yang A, Kaghad M, Caput D, McKeon F: On the shoulders of giants: p63, p73 and the rise of p53. Trends Genet 2002, 18:90-95

4. Yang A, Kaghad M, Wang Y, Gillett E, Fleming MD, Dotsch V, Andrews NC, Caput D, McKeon F: p63, a p53 homolog at 3q27-29, encodes multiple products with transactivating, death-inducing, and dominant-negative activities. Mol Cell 1998, 2:305-316

5. Deyoung MP, Ellisen LW: p63 and p73 in human cancer: defining the network. Oncogene 2007, 26:5169-5183

6. Finlan LE, Hupp TR: p63: the phantom of the tumor suppressor. Cell Cycle 2007, 6:1062-1071

7. Dohn M, Zhang S, Chen X: p63alpha and DeltaNp63alpha can induce cell cycle arrest and apoptosis and differentially regulate p53 target genes. Oncogene 2001, 20:3193-3205

8. Helton ES, Zhu J, Chen X: The unique NH2-terminally deleted (DeltaN) residues, the PXXP motif, and the PPXY motif are required 
for the transcriptional activity of the DeltaN variant of p63. J Bio Chem 2006, 281:2533-2542

9. Lane D, Levine A: p53 research: the past thirty years and the next thirty years, Cold Spring Harb Perspect Biol 2010, 2:a000893

10. Olivier M, Hollstein M, Hainaut P: TP53 mutations in human cancers: origins, consequences, and clinical use, Cold Spring Harb Perspect Biol 2010, 2:a001008

11. Vousden $\mathrm{KH}$, Prives $\mathrm{C}$ : Blinded by the light: the growing complexity of p53. Cell 2009, 137:413-431

12. Guo X, Mills AA: p63, cellular senescence and tumor development. Cell Cycle 2007, 6:305-311

13. Moll UM, Slade N: p63 and p73: roles in development and tumor formation. Mol Cancer Res 2004, 2:371-386

14. Keyes WM, Vogel H, Koster MI, Guo X, Qi Y, Petherbridge KM, Roop DR, Bradley A, Mills AA: p63 heterozygous mutant mice are not prone to spontaneous or chemically induced tumors. Proc Natl Acad Sci U S A 2006, 103:8435-8440

15. Flores ER, Sengupta S, Miller JB, Newman JJ, Bronson R, Crowley D, Yang A, McKeon F, Jacks T: Tumor predisposition in mice mutant for p63 and p73: evidence for broader tumor suppressor functions for the p53 family. Cancer Cell 2005, 7:363-373

16. McKeon F: p63 and the epithelial stem cell: more than status quo? Genes Dev 2004, 18:465-469

17. Senoo M, Pinto F, Crum CP, McKeon F: p63 Is essential for the proliferative potential of stem cells in stratified epithelia. Cell 2007, 129:523-536

18. Koster MI, Kim S, Mills AA, DeMayo FJ, Roop DR: p63 is the molecular switch for initiation of an epithelial stratification program. Genes Dev 2004, 18:126-131

19. Castillo-Martin M, Domingo-Domenech J, Karni-Schmidt O, Matos T, Cordon-Cardo C: Molecular pathways of urothelial development and bladder tumorigenesis. Urol Oncol 2010, 28:401-408

20. Moll R, Divo M, Langbein L: The human keratins: biology and pathology. Histochem Cell Biol 2008, 129:705-733

21. Cheng W, Jacobs WB, Zhang JJ, Moro A, Park JH, Kushida M, Qiu W, Mills AA, Kim PC: DeltaNp63 plays an anti-apoptotic role in ventral bladder development. Development 2006, 133:4783-4792

22. Urist MJ, Di Como CJ, Lu ML, Charytonowicz E, Verbel D, Crum CP, Ince TA, McKeon FD, Cordon-Cardo C: Loss of p63 expression is associated with tumor progression in bladder cancer. Am J Pathol 2002, 161:1199-1206

23. Signoretti S, Pires MM, Lindauer M, Horner JW, Grisanzio C, Dhar S, Majumder P, McKeon F, Kantoff PW, Sellers WR, Loda M: p63 regulates commitment to the prostate cell lineage. Proc Natl Acad Sci U S A 2005, 102:11355-11360

24. Cordon-Cardo C: Molecular alterations associated with bladder cancer initiation and progression. Scand J Urol Nephrol Suppl 2008 , 218:154-165

25. Park BJ, Lee SJ, Kim JI, Lee CH, Chang SG, Park JH, Chi SG: Frequent alteration of p63 expression in human primary bladder carcinomas. Cancer Res 2000, 60:3370-3374

26. Di Como CJ, Urist MJ, Babayan I, Drobnjak M, Hedvat CV, TeruyaFeldstein J, Pohar K, Hoos A, Cordon-Cardo C: p63 expression profiles in human normal and tumor tissues. Clin Cancer Res 2002, 8:494-501
27. Comperat E, Bieche I, Dargere D, Ferlicot S, Laurendeau I, Benoit G, Vieillefond A, Verret C, Vidaud M, Capron F, Bedossa P, Paradis V: p63 gene expression study and early bladder carcinogenesis. Urology 2007, 70:459-462

28. Comperat E, Camparo P, Haus R, Chartier-Kastler E, Bart S, Delcourt A, Houlgatte A, Francois R, Capron F, Vieillefond A: Immunohistochemical expression of p63, p53 and MIB-1 in urinary bladder carcinoma: a tissue microarray study of 158 cases. Virchows Arch 2006, 448:319-324

29. Koga F, Kawakami S, Fujii Y, Saito K, Ohtsuka Y, Iwai A, Ando N, Takizawa T, Kageyama Y, Kihara K: Impaired p63 expression associates with poor prognosis and uroplakin III expression in invasive urothelial carcinoma of the bladder. Clin Cancer Res 2003, 9:55015507

30. Koga F, Kawakami S, Kumagai J, Takizawa T, Ando N, Arai G, Kageyama Y, Kihara K: Impaired Delta Np63 expression associates with reduced beta-catenin and aggressive phenotypes of urothelial neoplasms. Br J Cancer 2003, 88:740-747

31. Fukushima H, Koga F, Kawakami S, Fujii Y, Yoshida S, Ratovitski E, Trink B, Kihara K: Loss of DeltaNp63alpha promotes invasion of urothelial carcinomas via $\mathrm{N}$-cadherin/Src homology and collagen/ extracellular signal-regulated kinase pathway. Cancer Res 2009, 69: 9263-9270

32. He Y, Wu X, Tang W, Tian D, Luo C, Yin Z, Du H: Impaired delta NP63 expression is associated with poor tumor development in transitional cell carcinoma of the bladder. J Korean Med Sci 2008, 23:825-832

33. Hibi K, Trink B, Patturajan M, Westra WH, Caballero OL, Hill DE, Ratovitski EA, Jen J, Sidransky D: AIS is an oncogene amplified in squamous cell carcinoma. Proc Natl Acad Sci U S A 2000, 97:54625467

34. Patturajan M, Nomoto S, Sommer M, Fomenkov A, Hibi K, Zangen R, Poliak N, Califano J, Trink B, Ratovitski E, Sidransky D: DeltaNp63 induces beta-catenin nuclear accumulation and signaling. Cancer Cell 2002, 1:369-379

35. Taniere P, Martel-Planche G, Saurin JC, Lombard-Bohas C, Berger F, Scoazec JY, Hainaut P: TP53 mutations, amplification of P63 and expression of cell cycle proteins in squamous cell carcinoma of the oesophagus from a low incidence area in Western Europe. $\mathrm{Br} J$ Cancer 2001, 85:721-726

36. Hoos A, Urist MJ, Stojadinovic A, Mastorides S, Dudas ME, Leung DH, Kuo D, Brennan MF, Lewis JJ, Cordon-Cardo C: Validation of tissue microarrays for immunohistochemical profiling of cancer specimens using the example of human fibroblastic tumors. Am J Pathol 2001, 158:1245-1251

37. Cordon-Cardo C, Dalbagni G, Saez GT, Oliva MR, Zhang ZF, Rosai J, Reuter VE, Pellicer A: p53 mutations in human bladder cancer: genotypic versus phenotypic patterns. Int J Cancer 1994, 56:347-353

38. George B, Datar RH, Wu L, Cai J, Patten N, Beil SJ, Groshen S, Stein J, Skinner D, Jones PA, Cote RJ: p53 gene and protein status: the role of p53 alterations in predicting outcome in patients with bladder cancer. J Clin Oncol 2007, 25:5352-5358

39. Basturk O, Khanani F, Sarkar F, Levi E, Cheng JD, Adsay NV: DeltaNp63 expression in pancreas and pancreatic neoplasia. Mod Pathol 2005, 18:1193-1198 